Gut, 1983, 24, 114-119

\title{
Measurement of gut hormonal peptides in biopsies from human stomach and proximal small intestine
}

\author{
M G BRYANT, S R BLOOM, J M POLAK, S HOBBS, W DOMSCHKE, \\ $S$ DOMSCHKE, P MITZNEGG, H RUPPIN, AND L DEMLING
}

From the Departments of Medicine and Histochemistry, Royal Postgraduate Medical School, Hammersmith Hospital, London, and Medizinische Klinik mit Poliklinik and Pharmakologisches Institut, University of Erlangen, Erlangen, West Germany

SUMMARY Using sensitive and specific radioimmunoassays, concentrations of hormonal peptides have been measured in small biopsies taken from the human stomach, duodenum, and proximal jejunum. Comparison is made of these hormone concentrations and the number of respective endocrine cells present determined by quantitative immunocytochemistry. Immunoreactive somatostatin, VIP, motilin, and gastrin were detected in all regions examined, whereas secretin and GIP were undetectable in antral extracts. Enteroglucagon-like immunoreactivity was present only at and beyond the ligament of Treitz, although a few enteroglucagon-producing cells were shown by immunocytochemistry in the duodenum. The variation of hormone concentration was found to be small in these biopsies of normal tissue within each region of the gut examined, indicating that representative hormone concentrations may be reliably obtained from small biopsy tissues. An attempt has been made to establish reference values for gut hormone concentrations in such biopsies; this may allow future study of any changes in concentration that may occur in pathological conditions.

Despite the extremely recent rapid growth of gastrointestinal endocrinology, the role of the gut hormones in human pathophysiology is still unclear. The development of plasma radioimmunoassays has shown that abnormality of gut hormone release is an important aspect of human alimentary disease. Clearly much additional information could be obtained by the determination of the distribution pattern of tissue hormonal content.

We have previously reported the distribution of the gut hormones in whole bowel specimens taken under anaesthesia from baboons and monkeys and also in surgical tissue from man. ${ }^{12}$ Although this has provided good baseline data, these are obviously of little value for diagnostic purposes. Tissue hormone concentrations in fresh bowel biopsy specimens taken from diseased regions of the gut may yield much valuable information, but, as yet, little data are available on the normal range of the gut hormones in such tissues.

This study was undertaken firstly to assess

Address for correspondence: Professor S R Bloom. Department of Medicine. Royal Postgraduate Medical School. Du ( ane Road. London W12 IIHS Received for publication 3 Junc $19 \times 2$ whether the gut hormones can be reliably measured in extracts of small biopsies taken in a standard manner, and, secondly, if so, to establish normal reference values for the concentrations of these hormones in such tissues taken from different regions of the human stomach and small intestine. Finally, the pattern of distribution of these hormones as determined by radioimmunoassay is compared with that of their respective cells of origin determined by immunocytochemistry.

\section{Methods}

SUBJECTS

Biopsies of mean weight $20 \mathrm{mg}$ were taken from the antrum, the first and second parts of the duodenum, at the ligament of Treitz and $40 \mathrm{~cm}$ beyond it of nine apparently normal subjects after a period of overnight fasting. Fully informed consent was obtained from each subject and full investigations, including barium meal, showed no evidence of any bowel disease. Histological examinations revealed that the mucosa was normal in all cases. The mean age of the subjects was $43 \pm 4$ years ( $\bar{x} \pm$ SEM) and their mean weight $74 \pm 3 \mathrm{~kg}$. Three parallel biopsies were taken from each region of the gut by means of a Rubens 
multiple biopsy instrument, so that comparative analyses of cyclic AMP, DNA, and protein content, as well as immunocytochemistry and radioimmunoassay of hormonal content, could be carried out. Previously described radioimmunoassays were used to measure secretin, ${ }^{3}$ pancreatic glucagon, ${ }^{4}$ enteroglucagon, ${ }^{1}$ vasoactive intestinal peptide (VIP) ${ }^{5}$ motilin ${ }^{6}$ and gastric inhibitory peptide (GIP). ${ }^{1}$

For somatostatin radioimmunoassay, antibodies were raised in rabbits with the hormone coupled to bovine serum albumin (BSA) using carbodiimide. The conjugate was emulsified in complete Freund's adjuvant before immunisation. The animals were given boost injections at three monthly intervals after primary immunisation and antisera were collected for testing 10 days after each boost. The antiserum selected for routine assay was used at a final dilution of $1: 16,000$ and showed no crossreaction with pancreatic glucagon, VIP, GIP, secretin, motilin, gastrin, pancreatic polypeptide, and CCK at a concentration of $2 \mathrm{nmol} /$ assay tube. The assay detection limit was $4 \mathrm{fmol}$ somatostatin/ tube. Radioiodination of $\mathrm{Tyr}^{11}$ somatostatin was carried out using a modification of the lactoperoxidase method. ${ }^{7}$ The resulting label was purified by gel chromatography on a $0.9 \times 60 \mathrm{~cm}$ column using Sephadex G25 eluted with $100 \mathrm{mmol} / \mathrm{l}$ formic acid containing $50 \mathrm{KIU} / \mathrm{ml}$ Trasylol and $1 \%$ human serum albumin. A specific activity of 900 $\mu \mathrm{Ci} / \mu \mathrm{g}$ was routinely achieved and the label remained stable at $-20^{\circ} \mathrm{C}$ for up to three months. For radioimmunoassay, each biopsy was weighed while still frozen and then boiled in $1 \mathrm{ml}$ water for five minutes to destroy proteolytic enzymes. After cooling, the volume of water was readjusted to $1 \mathrm{ml}$ and the tissue homogenised. The resulting tissue suspension was allowed to stand at $4^{\circ} \mathrm{C}$ for half an hour, with constant agitation, to allow the peptides to solubilise. After centrifugation at $2000 \mathrm{~g}$ for 10 minutes, the supernatant was saved and the tissue debris re-extracted with $1 \mathrm{ml} 100 \mathrm{mmol} / \mathrm{l}$ formic acid. The process of peptide solubilisation followed by centrifugation was repeated and both supernatants were pooled and stored at $-20^{\circ} \mathrm{C}$ until the time of assay. Each extract was assayed at two dilutions. The possibility that substances might be present in the biopsy extracts, which might interfere with antibody-antigen binding, thus giving rise to erroneous results, was investigated by performing serial dilutions of selected extracts in the assays and comparing the resulting changes in hormonal immunoreactivity with those of the diluted standards. In addition, known standard amounts of each hormone were added to varying amounts of the extracts and serial dilutions again assayed in order to determine if this exogenously added hormonal immunoreactivity could be reliably measured in the presence of the tissue extracts.

In order to assess the ability of each peptide hormone to withstand the extraction procedure and, in particular, to investigate whether any proteolytic enzymes, which might destroy the peptides, were still present after boiling the tissues, a series of pilot studies were performed. Human antral and duodenal biopsies were used as initial material, and the recoveries of exogenously added radioactively labelled hormones and also of endogenous hormones were monitored at each step of the process previously described. Labelled peptides were introduced into the system by adding to the water used for boiling the tissues. To determine the degree of damage caused to each peptide during extraction, an evaluation was made of the ability of the ${ }^{125}$ I-labelled hormones, recovered at each step, to bind to their respective antibodies. In order to assess the efficacy of this extraction method, the recovery of endogenous hormones was compared directly with that obtained from a previously described extraction method which was known to be effective for these substances. ${ }^{1}$ In this case, both extraction methods were carried out in parallel.

For quantitative immunocytochemistry, the biopsies were frozen in Arcton at $-157^{\circ} \mathrm{C}$ and then freeze-dried and fixed in benzoquinone vapour. ${ }^{8}$ The tissues were subsequently embedded in paraffin wax and serial $5 \mu$ sections cut. The endocrine cells were stained using a PAP peroxidase technique ${ }^{9}$ and quantification of cell number was carried out using the Quantimet 720 Image Analyser. ${ }^{10}$

For the determination of cyclic AMP, protein and DNA content, biopsies were frozen in liquid nitrogen and subsequently homogenised in 5\% trichloroacetic acid. After centrifugation, the supernatant was removed and washed five times in water-saturated diethyl ether. Residual ether was removed in a stream of nitrogen. Aliquots of the washed extracts were lyophilised and reconstituted in distilled water for cyclic AMP assay. The determination of cyclic AMP was carried out using a protein binding method modified for cyclic AMP as described by Brown and co-workers. ${ }^{11}$ Aliquots of the trichloroacetic acid homogenates were assayed for protein according to Lowry ${ }^{12}$ and nucleic acids were extracted by heating to $90^{\circ} \mathrm{C}$ for 15 minutes. DNA was estimated by a colorimetric method. ${ }^{13}$

\section{Results}

In all cases, extractable immunoreactivity from the biopsies diluted approximately parallel to the respective pure hormone standard curves (Figure). Furthermore, when known amounts of exogenous 


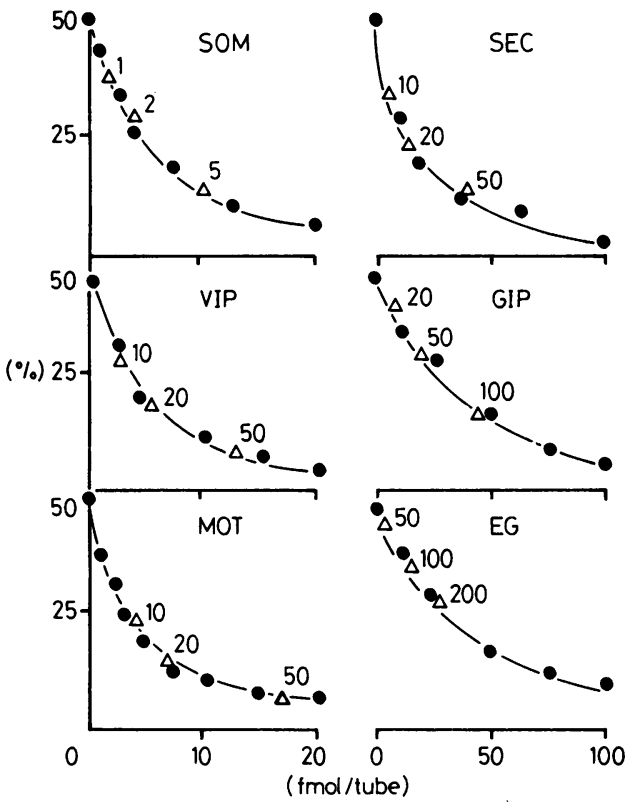

Figure Comparison of three dilutions (as $\mu$ l added per assay tube) of hormonal immunoreactivity extractable from tissue biopsies with the respective exogenous hormone standard curves showing parallelism. A pooled extract of all the ligament of Treitz biopsies was used.

hormones were added to varying amounts of the extracts, these were reliably measured against the background of endogenous immunoreactivity (Table 1). These results indicated that non-specific interference in the assays by substances in the extracts other than the peptides in question was minimal at the dilutions used in this study.

From the pilot studies it was found that less than $5 \%$ damage was caused to the labelled peptides by the extraction procedure, indicating that the proteolytic enzymes present in the tissues were adequately destroyed by boiling in water for five minutes. Similarly, recoveries of all peptides, except gastrin, were greater than $90 \%$ after the two homogenisations, showing that, once solubilised, the peptides are quantitatively recovered from the extracts. In the case of gastrin only $10 \%$ of added labelled peptide was recovered after pooling the two extracts. Similar concentrations of endogenous hormonal immunoreactivity were obtained with both extraction methods, indicating that, except for gastrin, the procedure used here was effective for the release of the peptides from the tissues.

Table 2 shows the distribution of the gut hormones as determined by radioimmunoassay. The corresponding distribution of the hormoneproducing cells, obtained by quantitative immunocytochemistry, is shown in Table 3 . A comparison of the cyclic AMP content of the biopsies from each region of the gut is shown in Table 4. Because an acid extraction solution was used which was optimal for most of the gut hormones but appeared to be very inefficient for the acidic peptide 'little' gastrin (G17), the distribution of immunoreactive gastrin has been omitted from Table 2. Gastrin-like immunoreactivity, however, was found to be present in all regions of the gut examined, being of highest concentration in the antrum $(280 \pm 68 \mathrm{pmol} / \mathrm{g}$ tissue wet weight) with similar amounts in the first part of the duodenum $(164 \pm 34 \mathrm{pmol} / \mathrm{g}$ tissue wet weight) and decreasingly distally down the bowel. The number of gastrin-producing cells, however, was much greater in the antrum than in any other region $\left(251 \pm 78\right.$ cells $\left./ \mathrm{mm}^{2}\right)$. Extractable immunoreactive VIP and somatostatin was also detectable in all biopsies. VIP concentration was maximal in the first part of the duodenum $(96 \pm 20 \mathrm{pmol} / \mathrm{g}$ tissue wet weight) with least occurring in the jejunum (15 \pm 4 $\mathrm{pmol} / \mathrm{g}$ tissue wet weight). High concentrations were also observed in the antrum. By radioimmunoassay,

Table 1 Measurement of known amounts of exogenously added hormones in presence of increasing volumes of biopsy extracts expressing results as percentage recoveries of added hormone in each extract volume

Extract volume tested (in $\mu$ llassay tube)

\begin{tabular}{llllllll}
\hline 1 & 2 & 5 & 10 & 20 & 50 & 100 & 200
\end{tabular}

Hormonc added

(in $\mathrm{pmol} / \mathrm{ml}$ extracts)

Somatostatin

VIP

Motilin

Sccretin

GIP

Enteroglucagon

$\begin{array}{lllll}87 & 105 & 95 & - & \\ - & - & 92 & 96 & 93 \\ - & - & 1111 & 92 & 97 \\ - & - & - & 93 & 94 \\ - & - & - & - & 89\end{array}$

-
93
97
94
89
-

-
-
-
94
112
107

$\begin{array}{ll}- & - \\ - & - \\ \overline{106} & - \\ 102 & 102\end{array}$

A pooled extract from all the ligament of Treitz hiopsies was used. 
Table 2 Radioimmunoassay determination of gut hormone concentration in small mucosal biopsies taken from human antrum, duodenum, and jejunum

\begin{tabular}{|c|c|c|c|c|c|c|}
\hline & Somatostatin & $V I P$ & Motilin & Secretin & $G I P$ & $\begin{array}{l}\text { Entero- } \\
\text { glucagon }\end{array}$ \\
\hline Antrum & $363 \pm 114$ & $26 \pm 9$ & $3 \pm 1$ & $<4$ & $<4$ & $<4$ \\
\hline Duodenum (1st part) & $270 \pm 69$ & $96 \pm 20$ & $55 \pm 10$ & $68 \pm 14$ & $51 \pm 9$ & $<4$ \\
\hline Duodenum (2nd part) & $206 \pm 78$ & $51 \pm 16$ & $76 \pm 11$ & $128 \pm 50$ & $72 \pm 7$ & $<4$ \\
\hline Ligament of Treitz & $200 \pm 65$ & $27 \pm 4$ & $34 \pm 7$ & $76 \pm 21$ & $46 \pm 7$ & $13 \pm 4$ \\
\hline Jejunum & $188 \pm 26$ & $15 \pm 4$ & $27 \pm 4$ & $41 \pm 7$ & $40 \pm 6$ & $13 \pm 3$ \\
\hline
\end{tabular}

Values are expressed as pmol hormone immunoreactivity/g tissue wet weight (mean \pm SEM, $n=9$ ).

somatostatin was relatively evenly distributed throughout the intestine. The distribution of somatostatin producing D-cells in the small intestine correlated closely with the radioimmunoassay data, but the greatest number of cells occurred in the antrum $\left(235 \pm 43\right.$ cells $\left./ \mathrm{mm}^{2}\right)$, whereas the highest concentration of somatostatin was found in the second part of the duodenum ( $438 \pm 42 \mathrm{pmol} / \mathrm{g}$ tissue wet weight). As VIP occurs mainly within fine nerve fibres in the gut mucosa and wall ${ }^{14}$ comparative quantitative immunocytochemistry was not possible, and values for VIP have therefore been omitted from Table 3.

The distribution patterns of secretin, GIP, and motilin were very similar, each hormone occurring in highest concentration in the duodenum and decreasing distally. GIP and secretin immunoreactivity was undetectable in the antrum, whereas very small amounts of immunoreactive motilin were found to be present in this region $(3 \pm 1 \mathrm{pmol} / \mathrm{g}$ wet weight). The distribution of the respective cells producing these hormones was in very good agreement with the radioimmunoassay data. Enteroglucagon was undetectable by radioimmunoassay proximal to the ligament of Treitz and was present in only low concentration in the lower jejunum $(13 \pm 3 \mathrm{pmol} / \mathrm{g}$ wet weight $)$. In no case was any pancreatic glucagon-like immunoreactivity detectable.

\section{Discussion}

The pattern of distribution of the gut hormones shown in this study correlates very closely with that seen in the primate and in surgical tissues taken from man. ${ }^{12}$ Except in the case of gastrin, ${ }^{15}$ no similar study has so far been carried out for the measurement of gut hormone concentrations in human small bowel biopsies. Rehfeld reports a 20 -fold difference between gastrin concentration in the antrum and that in the duodenal bulb, with the concentration decreasing gradually towards the distal duodenum. In this present study, the extraction procedure was designed to ensure good recoveries of most of the gut hormones, which have a near neutral or alklaline pI. Consequently, recovery was poor for the only really acidic hormone, little gastrin (G17). Thus, while the distribution of the gastrin-producing cells reported here compares very favourably with Rehfeld's data, only in the small intestine, where the less acidic big gastrin (G34) predominates, are the radioimmunoassay data in agreement. Somewhat unexpectedly, and of particular interest, are the small standard errors shown using these techniques. This would seem to indicate that the hormone-producing cells of the gut are scattered throughout the mucosa in a fairly regular manner and are not as unevenly distributed as appears to be the case for the $\mathrm{G}$ cell in

Table 3 Immunocytochemical quantification of number of endocrine cells in mucosal biopsies from human antrum. duodenum, and proximal jejunum (cells containing gastrin-like immunoreactivity indicated as gastrin-LI)

\begin{tabular}{lcccccc}
\hline & Sormatostatin & Gastrin-LI & Motilin & Secretin & GIP & $\begin{array}{l}\text { Entero- } \\
\text { glucagon }\end{array}$ \\
\hline Antrum & $235 \pm 43$ & $251 \pm 78$ & - & - & $3 \pm 2$ & - \\
Duodenum (1st part) & $127 \pm 22$ & $98 \pm 18$ & $78 \pm 20$ & $7 \pm 2$ & $31 \pm 9$ & $6 \pm 3$ \\
Duodenum (2nd part) & $92 \pm 23$ & $87 \pm 18$ & $60 \pm 10$ & $16 \pm 4$ & $30 \pm 8$ & $5 \pm 2$ \\
Ligament of Treitz & $68 \pm 10$ & $62 \pm 12$ & $65 \pm 14$ & $29 \pm 8$ & $34 \pm 7$ & $28 \pm 7$ \\
Jejunum & $59 \pm 31$ & $26 \pm 9$ & $50 \pm 22$ & $36 \pm 18$ & $15 \pm 4$ & $10 \pm 1$ \\
\hline
\end{tabular}

Values are expressed as the number of cells per $\mathrm{mm}^{2}$ of mucosa (mean \pm SEM. $n=9$ ) 
Table + Ciclic AMP content of mucosal biopsies from different regions of human gastrointestinal tract ( $\mathrm{pmol} / \mathrm{mg}$ protein) (mean $\pm S E M, n=9$ )

(iclic AMP content of mucosal biopsies (pmolimg protein)

\begin{tabular}{|c|c|c|c|c|}
\hline \multirow[b]{2}{*}{ Antrum } & \multicolumn{2}{|c|}{ Duodenum } & \multirow{2}{*}{$\begin{array}{l}\text { Ligament } \\
\text { of Treitz }\end{array}$} & \multirow[b]{2}{*}{ Jejumum } \\
\hline & (Ist part) & (2nd part) & & \\
\hline $9.9 \pm 2.8$ & $2(1)+ \pm \pm 5 \cdot 1)$ & $28 \cdot 5 \pm 0.1$ & $14 \cdot 9 \pm 2 \cdot 8$ & $17 \cdot 9 \pm 4 \cdot 11$ \\
\hline
\end{tabular}

the antrum. This, and the close correlation between the data obtained here and that observed in surgical specimens, leads to the speculation that small mucosal biopsies from the intestine can indeed be used to obtain representative hormonal concentrations for a particular region of the gut. Further weight is added to this by the close agreement in distribution pattern obtained by both radioimmunoassay and quantitative immunocytochemical techniques. These techniques should thus be of great value for the study of gut hormone pathology. Failure of gut hormone release in a particular disease state of the gut may be because of decreased numbers of endocrine cells or synthesis/release abnormalities. Clearly, application of this methodology could clarify such issues. By studying groups of patients with different gut diseases, even small changes in the normal distribution pattern of the gut hormones should be apparent and it should be possible to identify and characterise affected regions of the bowel. In this way, these methods may eventually be adopted for use in preoperative diagnosis of alimentary disease and future follow-up of treatment.

Perhaps one of the most exciting aspects arising from this study, for future research, is the suitability of these techniques for the study of locally acting substances within the gut - for example, VIP and somatostatin. Such substances, which act mainly on neighbouring tissues within the gut, rarely reach the peripheral circulatory system in biologically significant amounts in normal circumstances. Consequently, the physiology of these substances can be readily investigated only in tissues. This technique offers the possibility of tissue examination in the intact bowel of conscious subjects. By taking biopsies from the same region of the gut both before and after various intraluminal stimuli, it should be possible to study the pattern of release of such paracrine substances, and insight may thereby be gained into their physiological and pathophysiological roles.

This combination of techniques, involving the collection of multiple biopsies by a skilled endoscopist from particular regions of the gut and parallel analysis of hormonal content and endocrine cell number of the biopsies using specific radioimmunoassays and quantitative immunocytochemistry, should prove to be a useful tool for studying the endocrine and paracrine systems of the gut in both health and disease. Now that it seems possible to obtain reliable normal reference values for the distribution and tissue concentrations of the gut hormones in small biopsies the pattern in various disease states can be studied.

This work was supported by grants from the British Diabetic Association, Medical Research Council, and The Wellcome Foundation. Human serum albumin was kindly provided by the Lister Institute and pure porcine hormone was generously donated by Professor V Mutt (Karolinska Institute. Stockholm. Sweden). Tyr" ${ }^{11}$ somatostatin was a gift from Jean Rivier (Salk Institute, California, USA).

\section{References}

1 Bryant MG, Bloom SR. The distribution of the gut hormones in the primate intestinal tract. Gut 1979; 20: 653-9.

2 Bloom SR, Bryant MG, Cochrane JPS. Normal distribution and postprandial release of gut hormones. Clin Sci Molec Med 1975; 49: 3P.

3 Häcki WH, Bloom SR, Mitznegg $\mathrm{P}$ et al. Plasma secretin and pancreatic bicarbonate response to exogenous secretin in man. Gut 1977; 18: 191-5.

4 Alford FP, Bloom SR, Nabarro JDN. Glucagon levels in normal and diabetic subjects: use of a specific immunoabsorbent for glucagon radioimmunoassay. Diabetologia 1977; 13: 1-6.

5 Mitchell SJ, Bloom SR. Measurement of fasting and postprandial plasma VIP in man. Gut 1978; 19: 1043-8.

6 Bloom SR, Mitznegg P, Bryant MG. Measurement of human plasma motilin. Scand J Gastroenterol 1976; 2: suppl $39,47-52$.

7 Holohan KN. Murphy RF, Flanagan RW et al. Enzymic iodination of the histidyl residue of secretin: a radioimmunoassay of the hormone. Biochim Biophys Acta 1973; 322: 178-80.

8 Pearse AGE, Polak JM. Bifunctional reagents as vapour and liquid phase fixatives for immunohistochemistry. Histochem J 1975; 7: 179-86.

9 Sternberger L. The unlabelled antibody enzyme method. Inglewood Cliff, NJ: Prentice Hall, 1974: 142-61.

10 Polak JM. Pearse AGE, Gibson S. Cellular endocrinology of the gut and pancreas. In: Fujita T, ed. Endocrine gut and pancreas. Amsterdam: Elsevier, 1976.

11 Brown BL. Albano JDM. Ekins RP et al. A simple and 
sensitive saturation assay method for the measurement of adenosine $3^{\prime}: 5^{\prime}$-cyclic monophosphate. Biochem $J$ 1971; 121: 561-2.

12 Lowry $\mathrm{OH}$, Rosebrough NJ. Farr AL et al. Protein measurement with the folin phenol reagent. $J$ Biol Chem 1951; 193: 265-75.

13 Burton K. A study of the conditions and mechanism of the diphenylamine reaction for the colorimetric estimation of deoxyribonucleic acid. Biochem J 1956; 62:
315-23.

14 Bryant MG, Bloom SR. Polak JM et al. Possible dual role for vasoactive intestinal peptide as gastro-intestinal hormone and neurotransmitter substance. Lancet 1976; I: $991-3$.

15 Rehfeld JF. Stadil F. Malmstrom J et al. Gastrin heterogeneity in serum and tissue: a progress report. In: Thompson JC, ed. Gastrointestinal hormones. Austin and London: University of Texas Press. 1975. 